\title{
PRF: An Indispensible Adjunct in Implantology
}

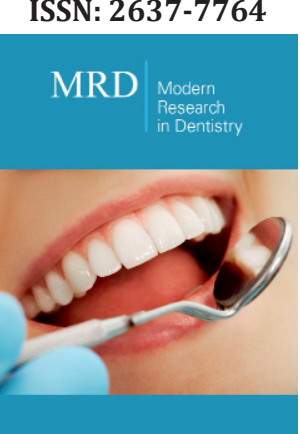

*Corresponding author: Ujjwal Gulati, Director and Consultant Oral and Maxillofacial Surgeon, INDIADENS, New Delhi, India

Submission: 祭 June 03, 2019

Published: 闻眥June 10, 2019

Volume 4 - Issue 2

How to cite this article: Ujjwal G, Mehvash Gulati, Deepak R. PRF: An Indispensible Adjunct in Implantology. Mod Res Dent. 4(2). MRD.000583.2019.

DOI: 10.31031/MRD.2019.04.000583

Copyright@ Ujjwal Gulati, This article is distributed under the terms of the Creative Commons Attribution 4.0 International License, which permits unrestricted use and redistribution provided that the original author and source are credited.

\author{
Ujjwal Gulati ${ }^{1 *}$, Mehvash Gulati ${ }^{2}$ and Deepak Rai ${ }^{3}$ \\ ${ }^{1}$ Director and Consultant Oral and Maxillofacial Surgeon, India \\ ${ }^{2}$ Chief Consultant General Dentistry, India \\ ${ }^{3}$ Consulatant Orthodontist and Implantologist, India
}

\section{Opinion}

PRF or Platelet Rich Fibrin is an autologous meshwork of polymerised fibrinogen molecules which contains additional blood components entrapped during the process of deriving this mineral from the ore of whole blood. Blood has traditionally been known as "Elixir of life" as it supplies tissues with auto regulated elements of generation, survival and destruction of cellular and sub cellular forms. Researchers have worked for decades to strike a balance in derivation of concentrates from blood which can be applied in various aspects of regeneration of tissues including qualitative enhancement of wound healing. The first breakthrough was in 1950's when Kingsley [1] first used the term PRP (Platelet rich plasma). Many researchers contributed to evolution of blood concentrates extraction techniques until Marx revolutionized the blood concentrates arena with his research work [2]. This sizzled a new craze across the medical fraternity and led to widespread usage of this modality. There were mixed results and then Marx et al established the norms and standards of preparation with minimum threshold of platelet count for tipping the balance in one's favour. Not much time had passed and Choukroun et al superceeded Marx et al with making of PRF (Platelet Rich Fibrin) which was a 100 percent autologous product [3]. It required a tabletop centrifuge which had to be spun at particular rpm (rounds per minute) for a particular time (Table 1). Although the angulation of glass/silica coated tubes containing blood kept in the housing of centrifuge was specific to the unit invented for the purpose. This was followed by development of variations of this technique based on change in rpm and duration of centrifugation.

Table 1

\begin{tabular}{|c|c|c|c|c|}
\hline $\begin{array}{l}\text { Type of Blood } \\
\text { Concentrate }\end{array}$ & $\begin{array}{c}\text { RPM of } \\
\text { Centrifuge }\end{array}$ & $\begin{array}{l}\text { Duration } \\
\text { of Spin }\end{array}$ & $\begin{array}{l}\text { Phlebotomy } \\
\text { Tube }\end{array}$ & Product Characteristics \\
\hline $\begin{array}{l}\text { Platelet Rich Fibrin } \\
\text { (PRF) }\end{array}$ & 3000 & 10 & $\begin{array}{l}\text { Glass/silica } \\
\text { coated }\end{array}$ & $\begin{array}{l}\text { A yellowish gel like clot as } \\
\text { middle layer between top layer of } \\
\text { acellular serum and bottom layer } \\
\text { of RBC's }\end{array}$ \\
\hline $\begin{array}{l}\text { Autologous Fibrin Glue } \\
\text { (AFG) [4] }\end{array}$ & $2400-2700$ & 2 & $\begin{array}{l}\text { Glass/silica } \\
\text { coated }\end{array}$ & $\begin{array}{l}\text { Superficial layer of pale yellow } \\
\text { AFG which can be drawn with } \\
\text { needle over syringe and bottom } \\
\text { layer of RBC's }\end{array}$ \\
\hline $\begin{array}{l}\text { Injectable Platelet Rich } \\
\text { Fibrin (i-PRF) [5] }\end{array}$ & 3300 & 2 & $\begin{array}{l}\text { Glass/silica } \\
\text { coated }\end{array}$ & $\begin{array}{l}\text { Reddish plasma top layer which } \\
\text { can be drawn with needle over } \\
\text { syringe and bottom layer of RBC }\end{array}$ \\
\hline $\begin{array}{l}\text { Concentrated Growth } \\
\text { Factor (CGF) [6] }\end{array}$ & $\begin{array}{l}\text { Acceleration } \\
2700 \\
2400 \\
2700 \\
3000 \\
\text { Deaccelera- } \\
\text { tion }\end{array}$ & $\begin{array}{l}30 \mathrm{sec} \\
2 \mathrm{~min} \\
4 \mathrm{~min} \\
4 \mathrm{~min} \\
3 \mathrm{~min} \\
36 \mathrm{sec}\end{array}$ & $\begin{array}{l}\text { Glass/silica } \\
\text { coated }\end{array}$ & $\begin{array}{l}\text { Four layers: } \\
\text { 1. Top layer: serum } \\
\text { 2. Interim layer: fibrin buffy } \\
\text { coat } \\
\text { 3. Liquid phase: growth } \\
\text { factors } \\
\text { 4. Lower phase: RBC }\end{array}$ \\
\hline $\begin{array}{l}\text { Titanium Prepared } \\
\text { PRF(T-PRF) [7] }\end{array}$ & 2800 & $12 \mathrm{~min}$ & $\begin{array}{l}\text { Grade } 4 \\
\text { Titanium } \\
\text { tubes }\end{array}$ & $\begin{array}{l}\text { Same as PRF but on scanning } \\
\text { Electronmicroscopy, fluorescence } \\
\text { microscopy and histomorpho- } \\
\text { metric analysis T-PRF had: Highly } \\
\text { organised fibrin network with } \\
\text { continuous integrity, Fibrin net- } \\
\text { work covered larger are }\end{array}$ \\
\hline
\end{tabular}


Tremendous amount of research work has gone into exploration of benefits of PRF and its variants and their application in the speciality of Implantology. PRF has found and established its role as more than an adjunct in many a procedure. It has been used to fill in the extraction sockets [4]. The advantages were lesser pain and faster and better regeneration of bone. It has been used successfully as a sole biomaterial for crestal sinus lift with great success. This negated the need for a bone graft. It is also used along with alloplastic and allogenic bone in sinus lifts where greater volumes are needed [5]. PRF is shredded into tiny bits and mixed with graft particles to fill in the sinus cavity. Sustained release of growth factors helps in accelerated maturation of the graft and keeps inflammation in check. AFG and PRF membrane have been used alone and in combination for repair of sinus perforation and many authors have reported successful results [10]. PRF membranes can be used alone or in conjunction with collagen membrane in guided bone regeneration. The AFG can be used to enhance the handling characteristics of bone graft material [6]. Heap of graft material is poured with AFG and allowed to polymerise for 5-10 minutes. PRF membranes with or without heat treatment can be used to cover the raw defects arising from harvesting full thickness connective tissue grafts from palate [7]. This promotes early epithelisation and reduces postoperative pain. The big question is "Why has PRF attracted so much of an interest in various aspects of tissue regeneration?" The answer lies in its extremely low risk benefit ratio. Use of PRF has multiple advantages with very few limitations. Preparation of PRF is a simple procedure which requires the use of a tabletop centrifuge. It is 100 percent autologous product with no chance of rejection or infection from a patient's body. Rather, it has been proven to possess antibacterial properties, which might bring down the chances of infection. It causes sustained release of growth factors entrapped within the fibrin clot as it undergoes gradual lysis $[8,9]$. This accelerates both soft and hard tissue regeneration and simultaneously keeps inflammatory mediators under check. It stimulates osteoblastic activity both in terms of proliferation and differentiation. PRF in membrane form has the potential to repel epithelial cells from the defect and promotes surface epithelisation making it an ideal aid for guided bone regeneration. It is biodegradable and the period may range from anywhere between 7-14 days. Heat treatment may increase the longevity for up to 28 days $[10,11]$. A biomaterial with all these advantages comes at a close to nil cost. The only requirement is a onetime investment into a centrifuge and every case requiring a phlebotomy set and vaccutainers. PRF definitely deserves the research attention and application craze it has attracted and has become an Indispensible tool in the armamentarium of an Implantologist.

\section{References}

1. Kingsley CS (1954) Blood coagulation; evidence of an antagonist to factor VI in platelet-rich human plasma. Nature 173: 723-724.

2. Marx RE, Carlson ER, Eichstaedt RM, Schimmele SR, Strauss JE, et al. (1998) Platelet-rich plasma: Growth factor enhancement for bone grafts. Oral Surg Oral Med Oral Pathol Oral Radiol Endod 85(6): 638-646.

3. Choukroun J, Adda F, Schoeffer C, Vervelle A (2000) An opportunity in perio implantology: The PRF. Implantodontie 42: 55-62.

4. Alzahrani AA, Murriky A, Shafik S (2017) Influence of platelet rich fibrin on post-extraction socket healing: A clinical and radiographic study. Saudi Dent J 29(4): 149-155.

5. Ali S, Bakry SA, Abd Elhakam H (2015) Platelet-rich fibrin in maxillary sinus augmentation: A systematic review. J Oral Implantol 41(6): 746753.

6. Sohn DS (2010) Lecture titled with sinus and ridge augmentation with CGF and AFG. Symposium on CGF and AFG, Japan.

7. Kulkarni MR, Thomas BS, Varghese JM, Bhat GS (2014) Platelet-rich fibrin as an adjunct to palatal wound healing after harvesting a free gingival graft: A case series. J Indian Soc Periodontol 18(3): 399-402.

8. Mourão CF, Valiense H, Melo ER, Mourão NB, Maia MD (2105) Obtention of injectable platelets rich-fibrin (i-PRF) and its polymerization with bone graft: technical note. Rev Col Bras Cir 42(6): 421-423.

9. Sacco L (2006) Lecture, International academy of implant prosthesis and osteoconnection. Lecture 12: 4 .

10. Tunalı M, Özdemir H, Küçükodacı Z, Akman S, Firatlı E (2013) In vivo evaluation of titanium-prepared platelet-rich fibrin (T-PRF): a new platelet concentrate. Br J Oral Maxillofac Surg 51(5): 438-443.

11. Oncu E, Kaymaz E (2017) Assessment of effectiveness of platelet rich fibrin in the treatment of schneiderian membrane perforation. Clin Implant Dent Relat Res 19(6): 1009-1014. 